\title{
The Effect of Ownership Concentration on Firm Value of Listed
} Companies

\author{
Oyerogba Ezekiel Oluwagbemiga ${ }^{1}$, OlaleyeOlugbenga Michael $^{2}$, Solomon \\ Adeoluwa Zaccheaus \\ 1Department of Commerce and Economic Studies, School of Human Resources DevelopmentJomo Kenyatta \\ University of Agriculture and Technology \\ 2Department of Commerce and Economic Studies, School of Human Resources DevelopmentJomo Kenyatta \\ University of Agriculture and Technology \\ 3Department of Commerce and Economic Studies, School of Human Resources DevelopmentJomo Kenyatta \\ University of Agriculture and Technology
}

\begin{abstract}
The purpose of this study is to explore the link between ownership concentration and the market value of listed companies using data from the selected 21 banks listed on the Nigeria Stock Exchange during the period of 2008 - 2012. The hypothesis formulated and tested for the study was that there is no significant relationship between ownership concentration and market value of listed companies. Ownership concentration was considered as independent variable while market value was considered as dependent variable. Ownership concentration was measured by the amount of stock owned by individual investors and large -block shareholders divided by total stock. Market value was determined using the stock prices. The firm specific control variables were loan performance, profitability and firm size of the selected companies. Descriptive statistics was used to analyze the data while least square regression method was used to draw inference on the relationship between ownership concentration and firm value. The result indicates that a positive significant relationship exists between a firm value and ownership concentration.
\end{abstract}

Keywords: Banking Sector, Firm Value, Ownership Concentration

\section{Introduction}

What are the characteristics of 'good' ownership structure? Does ownership structure matter for firm performance? Why certain firms have large block holders and others do not? Should the power of large shareholders be limited to avoid expropriation or encouraged to curb managerial discretion? These questions have been largely explored in corporate finance literature and we understand better now the intricacies of the relationship between ownership structure and firm performance.

But empirical evidence on the impact of shareholders with significant equity holdings on corporate performance remains ambiguous. Various authors using different samples of firms and different empirical strategies obtain different, difficult to compare and sometimes contradictory results. It is increasingly recognized that the problem in disentangling this relationship is largely due to the pervasive endogeneity of ownership which has to be taken into account in order to obtain unbiased results. But the existing empirical evidence also suggests that the relationship between ownership and performance may depend on the type of the firm and on the period of observation in the life of the firm.

The purpose of this paper is to explore more in details the relationship between ownership concentration and market value of listed companies for a sample of 21 listed banks in the Nigeria stock exchange (NSE) during the period 2008-2012. Ownership concentration was considered as independent variable while market value was considered as dependent variable. Ownership concentration was measured by the number of share of stock owned by individual investors and large -block shareholders divided by the total number of share of stock. Market value was determined using the stock prices of the selected companies

While the literatures indicates that ownership concentration curtails managerial self-interest and protects shareholders interest, this study investigated the effect of ownership concentration on the minority shareholder and other non-investing stakeholders looking at the instances where the will of a large shareholder overrides the decision of the management thereby constituting an agency problem. The rest of the paper is organized as follows. Section 2 highlights the previous relevant literature on ownership concentration and firm value. Section three addressed the methodology employed in carrying out the study. Presentation of data and analysis was done in section 4 while the study was concluded in section 5 . 


\section{Literature Review}

Ownership Concentration - It is generally accepted that ownership structure is an important component of corporate governance (Shleifer\&Vishny, 1986). The relationship between ownership structure and economic performance has been a topic of great interest in strategic management literature (Oswald \& John S. Jahera, 1991; \&Simerly, 1998; Bethel \&Liebeskind, 1993; Demsetz\&Villalonga, Ownership structure and corporate performance, 2001). Since Berle and Means (1932) it has been largely argued that ownership structure is positively related to firm profitability. Continuing this debate, other scholars have examined and generally given supporting evidences to the agency theory expectations (Jensen \&Meckling, 1976) that separation between ownership and control provides managerial incentives to diversification because of the personal benefits that managers would acquire from risk reduction. Indeed, large number of shareholders cannot exercise enough power to oversee managerial performance. Consequently, managers exercise more freedom in the use of firm resources as they would in case of a single shareholder or if the ownership would have been more concentrated (Shleifer\&Vishny, 1997). In studies of diversification strategy, it is found that managers assume more personal benefits (financial and reputational) in product or market diversification because of risk aversion, expense preference, and empire building (Thomsen \& Pedersen, 2000). Ownership concentration can counteract corporate diversification and gain more shareholder value. Agency theory argues that managers tend to increase their wealth and reputation by diversification and fast growth without maximizing firm market value (Jensen \&Meckling, 1976). Consequently, managers are not willing to downsize or reverse diversification if they are not pressured or obliged by ownership or external investors, to follow owners' interests in increasing firm market value. Therefore, according to the agency theory, managers' propensity to increase firm value depends, ceteris paribus, on the ownership structure. Supporting this theory, in a landmark work, Amihud and Lev (1981) examine empirically this theory, confirming that managers working in firms with large shareholders were less likely to invest in non-related mergers or acquisitions. These findings were supported by Hill and Snell (1989) who concluded that diversification, investment in R\&D, capital intensity, and ownership structure all determine firm productivity. They argue that large shareholders control is negatively related to product diversification. Another stream of research in corporate governance studies, takes into consideration the controlling mechanisms that induce managers to be aligned with shareholders' interests. An example of these controlling mechanisms is ownership concentration as it involves a trade-off between risk and incentive efficiency (Jensen \&Meckling, 1976; Demsetz, 1983; Shleifer\&Vishny, 1986). Larger shareholders might have stronger incentives to monitor and therefore, they should oblige managers to be aligned with their objective of increasing the value of their shares. But on the other side, Fama and Jensen (1983) argue that ownership concentration above a certain level will allow managers to become entrenched and expropriate the wealth of minority shareholders. This argument has leaded scholars in a hot debate over the possible non-linear relation of ownership concentration and firm performance. As ownership dispersion creates possibilities for free riding (Li \&Simerly, 1998) because of a lack of monitoring on management, a positive relation of ownership concentration with firm value is expected. Consistent with this monitoring theory, Shleifer and Vishny (1986) show the important role of large shareholders and how the market value is positively related to increasing values of shares held by larger shareholders. Nevertheless, recent studies have emphasized another source of agency problem created by rising ownership concentration that gives more power to a circumscribed number of shareholders that in turn might expropriate value from minority shareholders (La Porta, Lopez-de-Silanes, \&Shleifer, 1999). This is true for certain countries (i.e. in Europe) where the agency problem comes from the conflict between controlling owners and minority shareholders, instead of between ownership and management. In this case, large owners might be costly as they can redistribute wealth in both efficient and inefficient way from minority shareholders (Shleifer\&Vishny, Large shareholders and corporate control, 1986).

Another stream of research has examined the relationship between ownership structure and firm value suggesting that contrary to conventional wisdom, firm performance might influence ownership structure, but not vice versa (Demsetz, 1983; Demsetz\& Lehn, 1985; Chang, 2003). Despite this long debate, there is little empirical evidence on the effects of ownership structure in Africa as prior empirical literature has majorly provided documentation for U.S. and U.K. firms (De Miguel, Pindado, \& De La Torre, 2004). Furthermore, there are no studies on the effects of the recent financial crises over the relation between ownership concentration and firm performance. Our analysis fits in this research stream which aims in investigating the relation between ownership concentration and firm performance by giving empirical evidences on the influence of ownership structure over firm performance for all the listed commercial banks in Nigeria between 2008-2012. In addition we study the changes of this relation due to thefinancial crisis in $2009-2012$. We conclude by giving evidences of the changing relationship between ownership concentration and firm performance as effect of the financial crisis. 


\section{1) RESEARCH DESIGN}

\section{Methodology}

By means of an explanatory design the study examined the relationship that exists between ownership concentration and its market value of listed companies. An explanatory design is appropriate because the study intends to establish if there is a significant relationship between corporate capital structure and firm value.

\section{2) POPULATION OF THE STUDY.}

The population of this study consisted of the all the one hundred and seventy three companies listed on the Nigeria Stock Exchange within the period of 2008-2012.

\section{3) SAMPLE AND SAMPLING TECHNIQUES}

The study adopted the use of secondary data only which will be extracted from the annual financial statement of the selected banks and security and exchange commission facts book. Out of the population for the study,a sample size of twenty one banks was selected for the study. The three banks that fell during the 20092011 crises were not considered as relevant information concerning them were not available.

\section{4) ANALYTICAL PROCEDURE}

For the purpose of analysis, this study adopted both descriptive and inferential statistic. Descriptive statistics was used to determine the mean for the data. Least square regression methodwas used to determine the level of relationship between the two variables (Ownership Concentration and Firm Value)and also for testing of the hypothesis with the aid of the statistical package for social science (SPSS) version 17.0

The general formula for the study model was as follows;

$\mathrm{Y}=\beta_{0}+\beta_{1} \mathrm{X}_{1}+\beta_{2} \mathrm{X}_{2}+\beta_{3} \mathrm{X}_{3}+\beta_{4} \mathrm{X}_{4}+\mu$

Where;

$\mathrm{Y}=$ value of the Firm

$\mathrm{X}_{1}=$ Ownership Concentration

$\mathrm{X}_{2}=$ Size of the Firm

$\mathrm{X}_{3}=$ Profitability

$\mathrm{X}_{4}=$ Loan performance of the Firm.

In the model, $\beta 0=$ the constant term while the coefficient $\beta_{\mathrm{i}} \mathrm{i}=1 \ldots .4$ was used to measure the sensitivity of the dependent variable $(\mathrm{Y})$ to unit change in the predictor variables. $\mu$ is the error term which captures the unexplained variations in the model.

\section{1) TREND ANALYSIS RESULTS}

\section{Data Presentation And Analysis}

The study sought to determine the effects of ownership concentration on the market value of listed companies on the Nigeria Stock Exchange using data from the 21 listed banks between 2008-2012.

Figure 1 and 2 shows the trend analysis of ownership concentration for the companies for a period of five years. The mean ranges from $12.39 \%$ in 2008 to $5.08 \%$ in 2012 for individual large shareholders and $20.64 \%$ in 2008 and $26.28 \%$ in 2012 for corporate large shareholders. These values reveal that Nigerian corporate ownership is concentrated in the hand of individual shareholders and corporate entities. In figure 3, the trend analysis for stock prices revealed a decrease in year 2008 up to 2010. There was a significant decrease in the year 2008 from 42.50 to 18.40 in 2009 and 12.44 in the year 2010. The trend however, shows a very slight increase in the year 2011 and 2012. This fall of the stock prices may be as a result of the global financial crisis and the Nigeria banking industry crises witnessed between 2009 and 2011. However, the positive macroeconomic policies put in place by the government might be responsible for the slight improvement between 2011 and 2012.

Figure 4, trend analysis for loan performance revealed that there was considerable increase in the level of performance of loan in the selected companies over the period under consideration. The rise in loan recovery from 4.29 in 2008 to 8.26 in the year 2012 as measured by the percentage of recovered loan to the total loan indicates that Nigeria banks have been prudent in the assessment of debtors for credit facilities. This could be as a result of proper monitoring of the management by the large shareholders.

As indicated in Figure 5, the trend analysis for profitability in Nigerians listed companies falls slightly from 4.29 in the year 2008 to 3.16 in the year 2009 and 2.98 in the year 2010. However, there was an increase to 3.08 in the year 2011 and 3.30 in the year 2012 .

\section{2) INFERENTIAL RESULTS.}

In this study, R- square is 57\%. The result shows that ownership concentration and dependent variable stock prices are significantly positively correlated thus our hypothesis which predicts significant relationship between ownership concentration and firm value is supported. Furthermore, it was found that profitability and 
firm value are positively correlated and this relationship is statistically significant thus our hypothesis cannot be rejected. It means that companies with concentrated ownership make more profit than those with dispersed ownership. The relationship between firm value and firm size is positive but this relationship is not significant. This shows that the size of the firm has no significant effect on the value of the firm. Loan performance was found to be significantly positively correlated with stock prices (firm value). This could be as a result of proper monitoring of investment activities on the part of block shareholders.

\section{Conclusion}

The purpose of this study was to investigate whether there is any relationship between ownership concentration and market value of listed companies in the Nigeria stock exchange (NSE). 21 banks were selected which were listed on the Nigeria stock exchange during the period 2008-2012. Ownership concentration was considered independent variable and measured by the number of share of stock owned by individual investors and large block shareholders divided by the total stock. Firm value was taken as a dependent variable representing stock prices, while firm specific control variables were profitability, loan performance and firm size. The result indicates a positive relationship between ownership concentration, profitability, loan performance and stock prices. This findings support the findings ofBerle and Means (1932) which predicts a positive relationship between ownership structure and firm value. The results also confirmed the findings of Shleifer and Vishny (1986) which predicts a positive relationship between ownership control and firm performance. However, no significant relationship was found between stock prices and firm size. The aforementioned relationship was determined with the use of least square regression method.

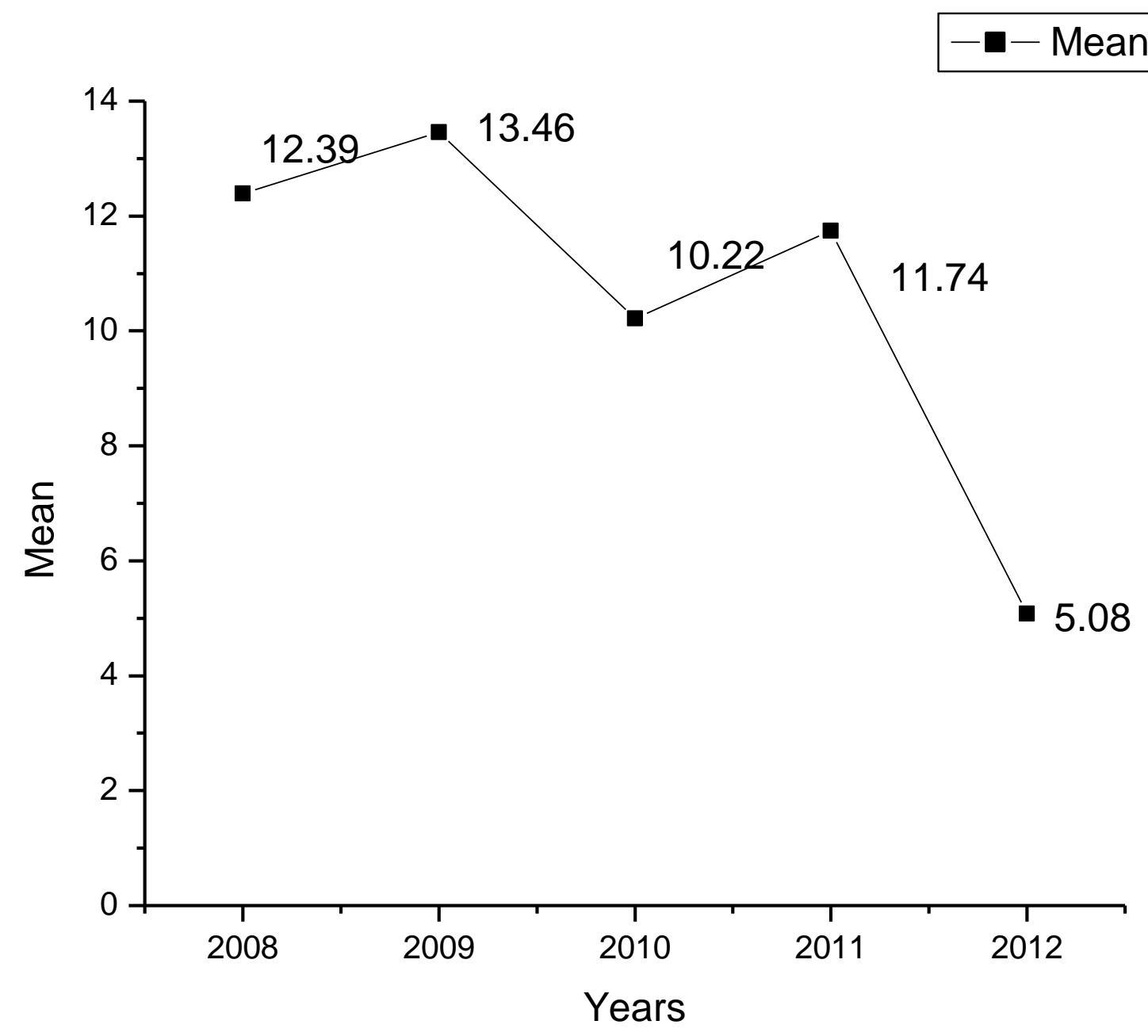

Figure 1: Trend analysis for Ownership Concentration (Individuals) 


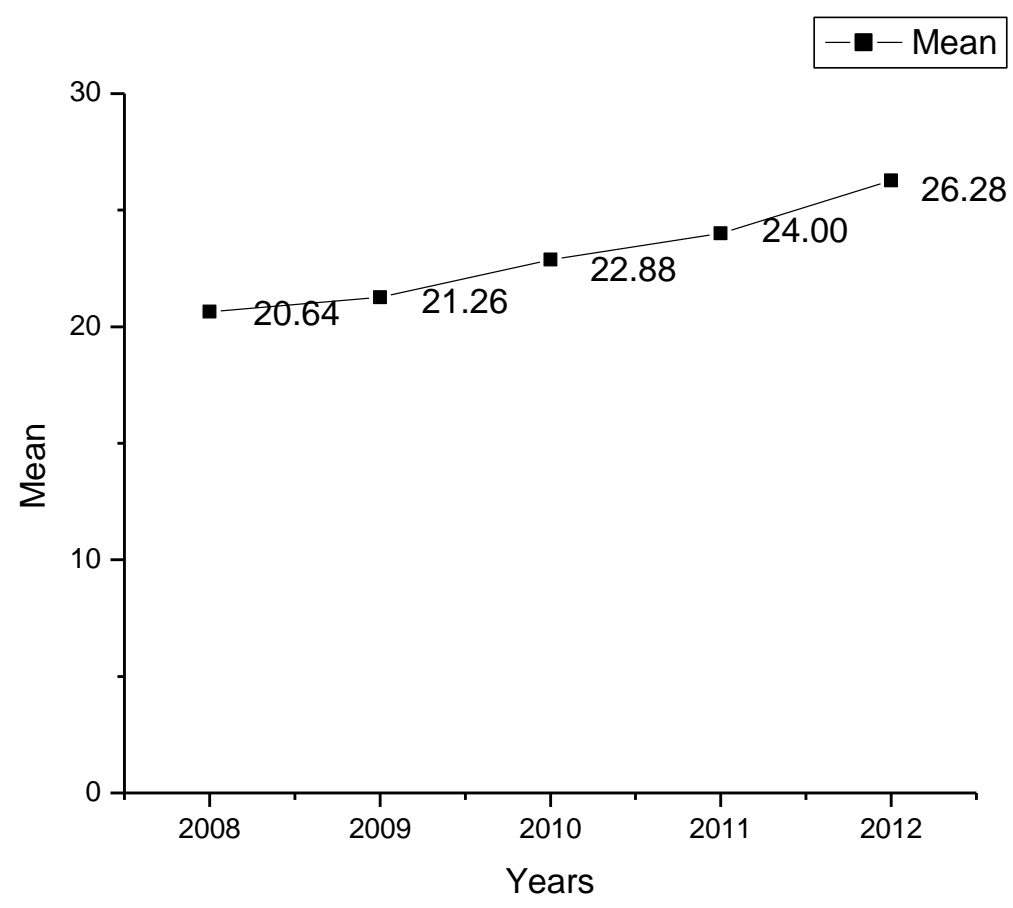

Figure 2: Trend analysis for Ownership Concentration ( Organization )

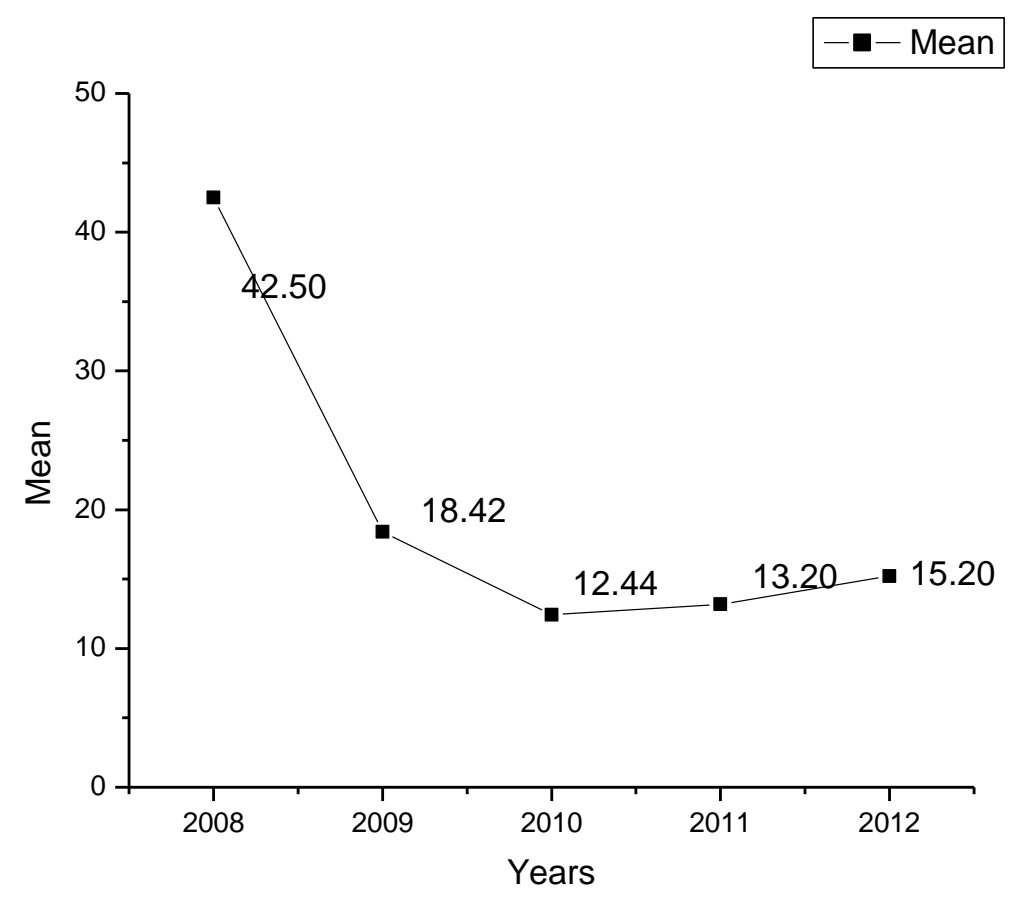

Figure 3: Trend analysis for stock prices 


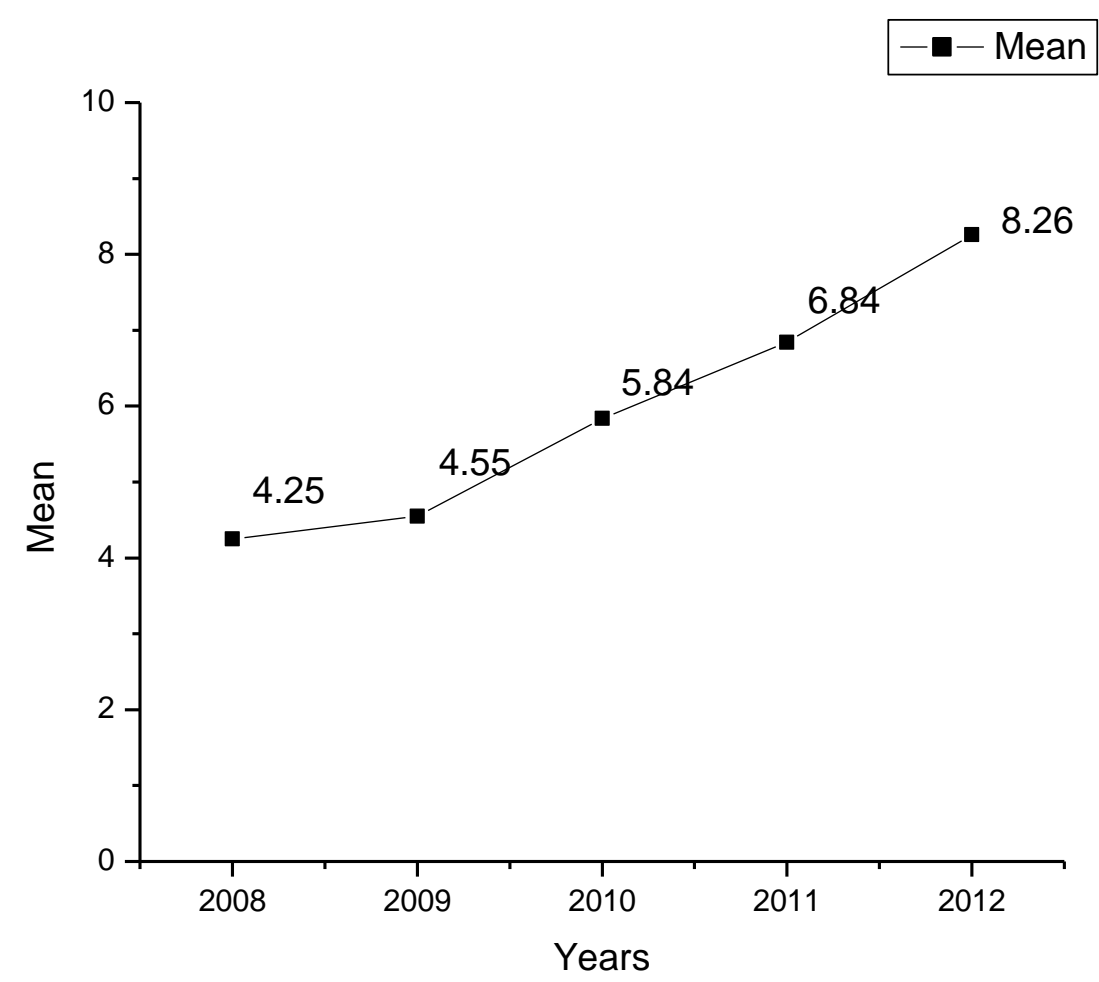

Figure 4: Trend analysis for loan performance

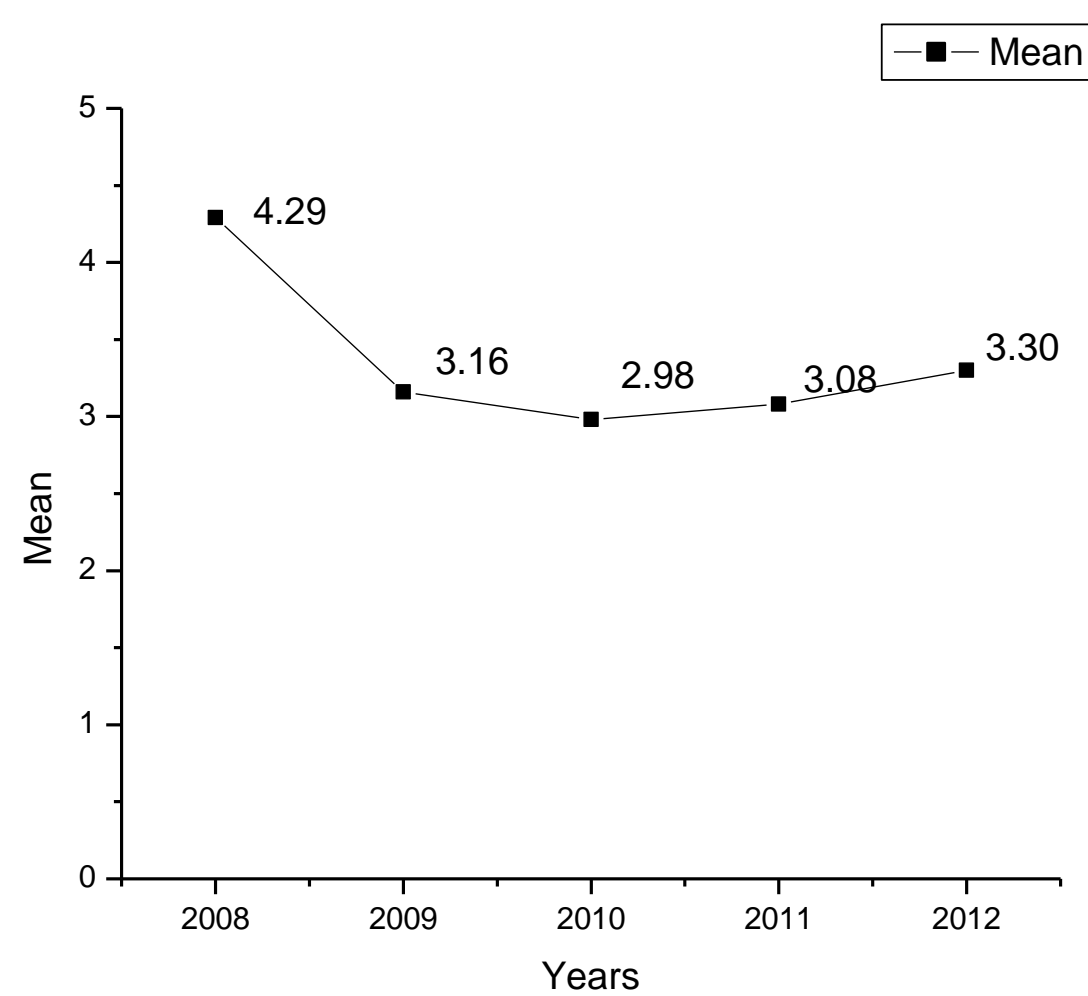

Figure 5: Trend analysis for profitability 
The Effect of Ownership Concentration on Firm Value of Listed Companies

TABLE 1.RESULTS OF REGRESSION ANALYSIS.

$\begin{array}{lcccc}\text { Variables } & \text { Coefficients } & \text { Std. Error } & \text { T. Statistic } & \text { Prob. } \\ \text { Size } & 0.0024 & 0.0045 & 0.0452 & 0.6524 \\ \text { OC } & 0.0496 & 0.0245 & 2.1368 & 0.0328 \\ \text { Profitability } & 0.0056 & 0.0046 & 0.6785 & 0.4952 \\ \text { Loan Performance } & 0.0775 & 0.0453 & 1.7126 & 0.0000 \\ \text { R- Square } & 0.5742 & & & \\ \text { Adjusted R- Square } & 0.5646 & & & \\ \text { S.E of Regression } & 0.1248 & & & \end{array}$

References

[1]. Amihud, Y., \& Lev, B. (1981).CorporationRisk Reduction as a Managerial Motive for Conglomerate Mergers. The Bell Journal of Economics, 12(2), 605-617.

[2]. Baker, G. P. (2004). CEO Incentives and Firm Size.Journal of Labor Economics, 22(4).

[3]. Berle, A., \& Means, G. (1932).The Modern Corporation and Private Property. New York: Harcourt, Brace, \& World. Bethel, J. E., \&Liebeskind, J. (1993, Summer). The effects of ownership structure on corporate restructuring. Strategic Management Journal, Vol. 14, Special Issue: Corporate Restructuring, 15-31.

[4]. Brealey, R. A., Myers, S. C., \& Marcus, A. J. (2007).Fundamentals of Corporate Finance. New York: McGraw-Hill.

[5]. Chang, S. J. (2003, Apr.). Ownership Structure, Expropriation, and Performance of Group- Affiliated Companies in Korea. The Academy of Management Journal, 46(2), 238-253.

[6]. De Miguel, A., Pindado, J., \& De La Torre, C. (2004, Dec.). Ownership Structure and Firm Value: New Evidence from Spain. Strategic Management Journal, 25(12), 1199-1207.

[7]. Demsetz, H. (1983, Jun.). The Structure of Ownership and the Theory of the Firm. Journal of Law and Economics, 26(2), 375-390.

[8]. Demsetz, H., \& Lehn, K. (1985, Dec.). The structure of corporate ownership: Causes and consequences. The Journal of Political Economy, 93(6), 1155-1177.

[9]. Demsetz, H., \&Villalonga, B. (2001).Ownership structure and corporate performance. Journal of Corporate Finance, 7,209-233.

[10]. Fama, E. F., \& Jensen, M. C. (1983, June).Separation of Ownership and Control. Journal of Law and Economics, 26(2), 301-325.

[11]. European Scientific Journal October edition vol. 8, No.22 ISSN: 1857 - 7881 (Print) e - ISSN 1857- 7431

[12]. Hill, C. W., \& Snell, S. A. (1988, Nov. - Dec.).External control, corporate strategy, and firm performance in research-intensive industries. Strategic Management Journal, 9(6), 577-590.

[13]. Hill, C. W., \& Snell, S. A. (1989, Mar.).Effects of Ownership Structure and Control on Corporate Productivity. The Academy of Management Journal, 32(1), 25-46.

[14]. Jensen, M. C., \&Meckling, W. H. (1976). Theory of the firm: Managerial behavior, agency costs and ownership structure. Journal of Financial Economics, 3(4), 305-360.

[15]. Jensen, M. C., \&Meckling, W. H. (1976, October). Theory of the Firm: Managerial Behavior, Agency Costs and Ownership Structure. Journal of Financial Economics, 3(4), 305-360.

[16]. Jensen, M. J. (1989). Eclipse of the public corporation. Harvard Business Review, 67(5), 61- 75. La Porta, R., Lopez-de-Silanes, F., \&Shleifer, A. (1999). Corporate Ownership Around the World. Journal of Finance, 54(2), 471-517.

[17]. Leech, D., \& Leahy, J. (1991, Nov.).Ownership Structure, Control Type Classifications and the Performance of Large British Companies. The Economic Journal, 101(409), 1418-1437. Lehmann, E., \&Weigand, J. (2000). Does the Governed Corporation Perform Better? Eurpean Finance Review, 4, 157-195.

[18]. Li, M., \&Simerly, R. L. (1998, Feb.).The Moderating Effect of Environmental Dynamism on the Ownership and Performance Relationship.Strategic Management Journal, 19(2), 169- 179.Morck, R., Nakamura, M., \&Shivdasani, A. (2000, Oct.).Banks, Ownership Structure, and Firm Value in Japan. The Journal of Business, 73(4), 539-567.

[19]. Morck, R., Shleifer, A., \&Vishny, R. (1988). Management Ownership and Market Valuation: An Empirical Analysis. Journal of Financial Economics, 20, 293-315.

[20]. Oswald, S. L., \& John S. Jahera, J. (1991, May). The Influence of Ownership on Performance: An Empirical Study. Strategic Management Journal, 12(4), 321-326.

[21]. Shleifer, A., \&Vishny, R. (1986).Large shareholders and corporate control. Journal of Political Economy, 94, 461488.

[22]. Shleifer, A., \&Vishny, R. W. (1997, Jun.). A Survey of Corporate Governance. The Journal of Finance, 52 (2), 737 783.

[23]. Thomsen, S., \& Pedersen, T. (2000, Jun.).Ownership Structure and Economic Performance in the Largest European Companies. Strategic Journal Management, 21(6), 689-705. 